\author{
Abstracta Iranica \\ Abstracta Iranica Revue bibliographique pour le domaine irano-aryen \\ Volume 34-35-36 | 2017 \\ Comptes rendus des publications de 2011-2013
}

\title{
Mohammad Gharipour, Irvin Cemil Schick (eds.). Calligraphy and Architecture in the Muslim World
}

Nourane Ben Azzouna

\section{(2) OpenEdition}

1 Journals

\section{Electronic version}

URL: http://journals.openedition.org/abstractairanica/41888

DOI: 10.4000/abstractairanica.41888

ISSN: 1961-960X

Publisher:

CNRS (UMR 7528 Mondes iraniens et indiens), Éditions de l'IFRI

\section{Electronic reference}

Nourane Ben Azzouna, « Mohammad Gharipour, Irvin Cemil Schick (eds.). Calligraphy and Architecture in the Muslim World ", Abstracta Iranica [Online], Volume 34-35-36 | 2017, document 17, Online since 30 December 2016, connection on 29 September 2020. URL : http://journals.openedition.org/ abstractairanica/41888 ; DOI : https://doi.org/10.4000/abstractairanica.41888

This text was automatically generated on 29 September 2020.

Tous droits réservés 


\title{
Mohammad Gharipour, Irvin Cemil Schick (eds.). Calligraphy and Architecture in the Muslim World
}

\author{
Nourane Ben Azzouna
}

\section{REFERENCES}

Mohammad Gharipour, Irvin Cemil Schick (eds.). Calligraphy and Architecture in the Muslim World. Edinburgh, Edinburgh Univerity Press, 2013, 532 p., 317 color illust. ISBN: 9780748669226

1 This volume is a large collection of 28 articles dedicated to the question of calligraphy in architecture in the 'Muslim' World. The articles or chapters were authored by a wide variety of specialists such as artists, art critics, art historians, and historians. As stated in the introduction, the main question addressed is the function of calligraphy in architecture. Was calligraphy meant to be read? How? And by whom? Was it supposed to communicate a message through its text (indicative, commemorative); its shape(s) (iconographic, imagistic); or simply its presence (iconic, symbolic)? Or was it purely ornamental (for instance framing the architectural forms)? How did calligraphy influence the perception and experience of a building or an urban context (for instance by orienting the circulation or by punctuating it with pauses)? How did it interact with the oral and performative life of a building (recitation, prayer, chant...)? Did epigraphy have various roles depending on the geographical, historical and cultural contexts?

2 The 28 chapters cover the entire scope of the Islamic world from al-Andalus to China as of the rise of Islam to modernity. They are not arranged geographically nor chronologically but grouped into six major themes: A- Sites; B- Style vs. content; CPatronage; D- Artists; E- Regional; F- Modernity. However tempting a thematic approach may be, this plan is puzzling for it induces a continual back-and-forth through space and time. Parts A (Sites) and E (Regional) overlap and could have been 
placed successively. Several chapters would have benefited from being grouped, particularly ch. 5 ("The Qur'anic inscriptions of the Minaret of Jām in Afghanistan", by Ulrike-Christiane Lintz) and ch. 12 ("Sovereign Epigraphy in Location: Politics, Devotion and Legitimisation around the Quṭb Minār, Delhi”, by Johanna Blayac); ch. 1 ("Inscribing the Square: The Inscriptions on the Maidān-i Shāh in Ișfahān", by Sheila S. Blair, on the inscriptions designed by the chief calligrapher of Shāh 'Abbās, 'Alī Riżā 'Abbāsī) and ch. 16 (on the same calligrapher: "An Art Ambassador: The Inscriptions of "Alī Reżā 'Abbāsī”, by Saeid Khaghani); or ch. 8 and 22 (on Chinese mosques: "Calligraphy in Chinese Mosques: At the Intersection of Arabic and Chinese Calligraphy", by Barbara Stöcker-Parnian, and "Space and Calligraphy in the Chinese Mosque", by Sadiq Javer). Other themes, especially style vs. content and patronage, underlie virtually every paper.

Two articles that focus on iconic Islamic monuments in predominantly non-Muslim contexts are interesting to underline: the articles on the minarets or victory towers of Jām (1174 or 1194) and Delhi (ca. 1195-1236 and later additions), which are discussed in ch. 5 and 12. The authors rely on a detailed knowledge of the historical and cultural contexts, and a precise survey of the inscriptions, in order to show that in both cases, the epigraphic programs, which mainly consist of Qur'anic excerpts and foundation inscriptions, stress the fundamentals of Muslim faith (the shahāda, God as The Creator, the Throne verse...), and the victory of Islam over idolatry. At the same time, these inscriptions appear as important historical sources, especially about the titles and sovereign discourses of the Ghurid sultans and their successors in northern India. Ch. 5 also proposes a reading of the inscriptions as a promotion of the Karrāmì doctrine, but this interpretation seems more speculative.

It may be regretted that not all papers include a transcription or a transliteration of the inscriptions discussed and a plan of their distribution in the building. The general paleographic analyses would have probably benefited from more cooperation between architectural historians, epigraphists and paleographers. By all means, the book shows the importance of a multifold approach to epigraphy, as well as the variety of situations, questions and possible interpretations. The content of architectural inscriptions varies according to the secular or religious nature of the building; the religious sensibilities, political claims or even gender of the patron (ch. 11, “'The Pen Has Extolled Her Virtues': Gender and Power within the Visual Legacy of Shajar al-Durr in Cairo", by Caroline Olivia M. Wolf); and the audience. Various types of inscriptions may be associated with different places, as well as materials, shapes and sometimes colors. For instance, religious, notably Qur'anic inscriptions or invocations often stand out from foundation inscriptions or artists signatures (esp. ch. 1, 16, and ch. 23 “ Medium and Message in the Monumental Epigraphy of Medieval Cairo", by Bernard O'Kane). The use of certain shapes can be anachronistic (ch. 7, "The Revival of Küfi Script During the Reign of Sultan Abdülhamid II", by İrvin Cemil Schick), and a building may have several layers of inscriptions corresponding to its different uses or lives (ch. 4, "Wall-Less Walls: The Calligraphy at the Hadži Sinanova Tekija in Sarajevo", by Snježana Buzov). 


\section{AUTHORS}

NOURANE BEN AZZOUNA

Université de Strasbourg 